\title{
When is illegality a defence to a tort?
}

\author{
Liron Shmilovits ${ }^{* \dagger}$ \\ University of Cambridge, Cambridge, UK \\ * Author e-mail: 1s621@cam.ac.uk
}

(Accepted 1 April 2021)

\begin{abstract}
The illegality defence is an important element of private law, but its operation has been unpredictable. In Patel v Mirza, the Supreme Court opted for a flexible approach, which does not increase predictability. This approach was recently confirmed in Henderson $v$ Dorset Healthcare University NHS Foundation Trust and Stoffel \& Co $v$ Grondona. I propose a principle to guide the application of the illegality defence in tort: namely, the claim fails for illegality if the claimant's harm is the ordinary result of the claimant's wrongdoing. It is argued that the guiding principle: (i) substantially explains the case law; (ii) is normatively defensible; and (iii) makes the defence much more predictable.
\end{abstract}

Keywords: private law; torts; tort defences; illegality; ex turpi causa; Patel v Mirza

\section{Introduction}

If I break the law, and suffer loss, can I recover? Suppose I pay a hitman, only to discover him to be an impostor, who pockets the fee without killing anyone at all. Can I sue the pseudo-assassin for fraud? In legal terms, the question is: does the illegality defence defeat my claim? English law does not have a simple answer to this question.

The answer, such as it is, is found in Patel v Mirza, decided by the Supreme Court in 2016. The Patel test is whether recovery by the wrongdoer 'would be harmful to the integrity of the legal system'. To apply this test, we consider (putting it briefly): the purpose of the transgressed prohibition; relevant policy interests; and proportionality. ${ }^{2}$

In 2020, the primacy of the Patel test for tort claims was confirmed by two unanimous decisions of the Supreme Court: Henderson v Dorset Healthcare University NHS Foundation Trust and Stoffel \& Co $v$ Grondona. It is now beyond doubt that Patel is the standard for all civil claims tarnished by illegality. ${ }^{3}$

Patel was the culmination of a decades-long debate over the correct approach to illegality. Patel has been praised and criticised, ${ }^{4}$ but it is here to stay, especially after Henderson and Stoffel. My purpose is not to re-open or replace Patel, but to guide its application. I propose a 'Guiding Principle' for the application of the illegality defence in the tort sphere. This Guiding Principle is that the claim should

\footnotetext{
${ }^{\dagger}$ Fellow of St Catharine's College, Cambridge. I wish to thank Nicholas McBride and several anonymous reviewers, whose comments greatly improved this paper. All mistakes are mine.

${ }^{1}$ [2016] UKSC 42, [2017] AC 467 at [120] (Lord Toulson).

${ }^{2}$ Ibid, at [120].

${ }^{3}$ Respectively: [2020] UKSC 43, [2020] 3 WLR 1124 at [76] (Lord Hamblen); [2020] UKSC 42, [2020] 3 WLR 1156 at [27] ff (Lord Lloyd-Jones).

${ }^{4}$ Praise: A Burrows 'Illegality after Patel v Mirza' (2017) 70 Current Legal Problems 55; criticism: J Goudkamp 'The end of an era? Illegality in private law in the Supreme Court' (2017) 133 Law Quarterly Review 14; G Virgo 'The state of illegality' (2019) 31 Singapore Academy of Law Journal 747.

(c) The Author(s), 2021. Published by Cambridge University Press on behalf of The Society of Legal Scholars. This is an Open Access article, distributed under the terms of the Creative Commons Attribution licence (http://creativecommons.org/licenses/by/4.0/), which permits unrestricted re-use, distribution, and reproduction in any medium, provided the original work is properly cited.
} 
fail if the claimant's harm is the ordinary result of the claimant's wrongdoing. This principle, I submit, is sound empirically and normatively: empirically, since it substantially explains the case law before and after Patel; normatively, because it is objectively defensible. This normative justification is that claimants who take an illegal risk should not shift the downside cost to others.

The reason my inquiry is limited to tort claims is that the application of the defence depends on the cause of action. Illegality is treated differently in tort cases than, say, in contract, unjust enrichment or property cases. ${ }^{5}$ The primacy of the Patel test has not eradicated this discrepancy. Indeed, the Patel test itself applies differently to different causes of action. ${ }^{6}$ I do not say the Guiding Principle has no relevance to non-tort claims; I say it is a matter for further research.

The paper is structured as follows. Part 1 set outs the problem: why we need a Guiding Principle on top of the judicial guidance in Patel, Henderson and Stoffel. Part 2 presents the solution: the Guiding Principle. Part 2 also demonstrates that the Guiding Principle explains the main strands in the case law. Part 3 expounds the normative justification for the Guiding Principle, namely risk-taking.

Incidentally, in Patel itself, the nine Justices disagreed on the phony assassin hypothetical. Lords Neuberger and Sumption explicitly favoured recovery. ${ }^{7}$ Lord Toulson (with whom Lady Hale and Lords Kerr, Wilson and Hodge agreed) suggested the opposite. ${ }^{8}$ Lords Mance and Clarke did not address the hypothetical, but their comments seemed to entail recovery from the fraudster. ${ }^{9}$ Happily, there was no murder plot; the discussion was obiter dicta.

\section{Problem}

It was no overstatement for Professor Goudkamp to call Patel 'a pivotal moment in English private law. ${ }^{10}$ It capped decades of convulsions, which had seen a succession of tests wax and wane: what the claimant bargained for; ${ }^{11}$ public conscience; ${ }^{12}$ indeterminate standard of care; ${ }^{13}$ reliance; ${ }^{14}$ inextricable link (also known as sufficient connection); ${ }^{15}$ causation (in narrow and wide varieties); ${ }^{16}$ and, finally, general public policy. ${ }^{17}$ These ephemeral tests were illuminated, or obscured, by Latin maxims such as ex dolo malo non oritur action, locus poenitentiae, in pari delicto and policy considerations aplenty. ${ }^{18}$ The Law Commission intervened, and then retreated, largely leaving the matter to the judges. ${ }^{19}$ In 2014, Lord Mance condemned the law of illegality, extra-judicially, as 'an unhappy mix of rigid rules and value judgments [with] unpredictable and haphazard consequences'. ${ }^{20}$

In 2014-2015, the debate escalated as the Supreme Court considered illegality three times and split into two camps: one, identified with Lord Toulson, advocated a discretionary, policy-based approach;

\footnotetext{
${ }^{5}$ See eg Saunders v Edwards [1987] 1 WLR 1116 (CA) at 1125D-1126H (Kerr LJ); Gray v Thames Trains Ltd [2008] EWCA Civ 713, [2009] 1 AC 1339 at [20] (Sir Anthony Clarke MR); Allen v Hounga [2014] UKSC 47, [2014] 1 WLR 2889 at [25] ff (Lord Wilson); Henderson, above n 3, at [77] (Lord Hamblen); Burrows, above n 4, at 66 fn 28.

${ }^{6}$ Patel, above n 1, at [116] (Lord Toulson).

${ }^{7}$ At least in unjust enrichment: Patel, above n 1, at [176], [254]; cf S Todd 'Professional negligence in 2018: the year in review' (2018) 35(1) Journal of Professional Negligence 6 at 31.

${ }^{8}$ Patel, above n 1 , at [116].

${ }^{9}$ Ibid, at [192], [197], [202], [211], [214].

${ }^{10}$ Goudkamp, above n 4 , at 14 .

${ }^{11}$ Murphy v Culhane [1977] 1 QB 94 (CA) at 98E-H (Lord Denning MR).

${ }^{12}$ Euro-Diam Ltd $v$ Bathurst [1990] 1 QB 1 (CA) at 35B-C (Kerr LJ).

${ }^{13}$ Pitts $v$ Hunt [1991] 1 QB 24 (CA) at 50 (Balcombe LJ).

${ }^{14}$ Tinsley $v$ Milligan [1994] 1 AC 340 (HL) at 370C-D (Lord Browne-Wilkinson).

${ }^{15}$ Cross v Kirkby (2000) Times, 5 April (CA) at [76] (Beldam LJ).

${ }^{16}$ Gray $v$ Thames Trains Ltd [2009] UKHL 33, [2009] AC 1339 at [29].

${ }^{17}$ Allen $v$ Hounga, above $\mathrm{n}$ 5, at [42] (Lord Wilson).

${ }^{18}$ See E Murphy 'The ex turpi causa' (2016) 32 Journal of Professional Negligence 241 at 246; Virgo, above n 4, at 750-754; Lord Sumption 'Reflections on the law of illegality' (2012) 20 Restitution Law Review at 1, 3-8.

${ }^{19}$ Law Commission The Illegality Defence in Tort (Law Com CP No 160, 2001); Law Commission The Illegality Defence (Law Com CP No 189, 2009); Law Commission The Illegality Defence (Law Com No 320, 2010) esp 4.26-4.27.

${ }^{20} \mathrm{~J}$ Mance 'Ex turpi causa - when Latin avoids liability' (2014) 18 Edinburgh Law Review 175 at 176.
} 
the other, led by Lord Sumption, supported a more mechanistic, rules-based approach. ${ }^{21}$ In this trio of cases, their Lordships agreed on the outcomes, but not the reasoning. In the last case, the President, Lord Neuberger, called for a showdown, in an enlarged panel, to settle the question of illegality once and for all. ${ }^{22}$

It fell to the lot of Mr Patel to be the hero, or anti-hero, of this showdown, and earn a dubious immortality. He had transferred $£ 620,000$ to a Mr Mirza, with a view to profiting from insider trading. Mirza was supposed to invest the money, based on insider information. But Mirza did not invest the money, nor return it. He just kept it for himself. So Patel sought restitution for unjust enrichment. Mirza rested his defence on the illegality of insider trading. ${ }^{23}$ In July 2016, when the case reached the Supreme Court, the illegality saga reached its climax.

In Patel v Mirza, a panel of nine divided six to three on the approach to illegality. Policy carried the day. The result - recovery - was unanimous. There were five separate speeches. Lord Toulson wrote the leading speech for the pro-policy majority. Lord Sumption gave the salient speech for the pro-rules minority.

Initially, there were academic doubts as to whether Patel, being an unjust enrichment case, applied to tort claims. ${ }^{24}$ The case law has dissipated these doubts. ${ }^{25}$ Patel is the test for tort claims tainted by illegality.

It is right at this stage to quote in full Lord Toulson's policy-based test for when illegality is a defence (approved by an absolute majority of the panel $^{26}$ ):

[120] The essential rationale of the illegality doctrine is that it would be contrary to the public interest to enforce a claim if to do so would be harmful to the integrity of the legal system (or, possibly, certain aspects of public morality, the boundaries of which have never been made entirely clear and which do not arise for consideration in this case). In assessing whether the public interest would be harmed in that way, it is necessary (a) to consider the underlying purpose of the prohibition which has been transgressed and whether that purpose will be enhanced by denial of the claim, (b) to consider any other relevant public policy on which the denial of the claim may have an impact and (c) to consider whether denial of the claim would be a proportionate response to the illegality, bearing in mind that punishment is a matter for the criminal courts.

Here lies the problem this paper seeks to solve. The problem with the Patel test is unpredictability. It is composed of three discretionary elements in pursuit of an abstract, arguably question-begging goal, namely 'the integrity of the legal system'. It is hard to imagine a less specific aspiration.

Subsequent case law has only expanded the discretion. In Henderson, Lord Hamblen, delivering the judgment of the Court, interpreted element (a) to include any policy reasons against the claim: it is not 'confined to the specific purpose of the prohibition transgressed'. Even the supposedly-jettisoned concept of reliance is a 'relevant factor', though not a dispositive one. ${ }^{27}$ The lingering relevance of reliance is corroborated in Stoffel. ${ }^{28}$ Rightly or wrongly, the discretion in Patel is maximal.

\footnotetext{
${ }^{21}$ Allen $v$ Hounga, above n 5; Les Laboratoires Servier v Apotex Inc [2014] UKSC 55, [2015] AC 430; Bilta (UK) Ltd v Nazir (No 2) [2015] UKSC 23, [2016] AC 1; see also N Strauss ‘Ex turpi causa oritur actio?' (2016) 132 Law Quarterly Review 236; Virgo, above $\mathrm{n}$, at $754 \mathrm{ff}$.

${ }^{22}$ Bilta, ibid, at [15].

${ }^{23}$ Criminal Justice Act 1993, s 52.

${ }^{24}$ Murphy, above n 18, at 248-249; Goudkamp, above n 4, at 17; cf Burrows, above n 4, at 59, 66.

${ }^{25}$ McHugh v Okai-Koi [2017] EWHC 1346 (QB) at [18]-[22] (Judge Pittaway); Singularis Holdings Ltd v Daiwa Capital Markets Europe Ltd [2018] EWCA Civ 84, [2018] 1 WLR 2777 at [1], [32](ii) (Sir Geoffrey Vos C); Vald Nielsen Holding A/S $v$ Baldorino [2019] EWHC 1926 (Comm) at [704] (Jacobs J); Bank St Petersburg PJSC v Arkhangelsky [2020] EWCA Civ 408 at [87] (Sir Geoffrey Vos C); Henderson, above n 3, at [76] (Lord Hamblen).

${ }^{26}$ Patel, above n 1, at [174] (Lord Neuberger); Lady Hale, Lord Kerr, Lord Wilson and Lord Hodge joined Lord Toulson's speech.

${ }^{27}$ Henderson, above $\mathrm{n} 3$, at [116]-[120].

${ }^{28}$ Stoffel, above n 3, at [43] (Lord Lloyd-Jones).
} 
This vagueness did not elude the Justices who decided Patel. Lord Neuberger, who sided with the policy-majority, confessed to finding the test too discretionary at first. ${ }^{29} \mathrm{He}$ accepted it eventually as 'the best guidance that can sensibly be offered at the moment. Experience shows that it is simply not possible to identify a more helpful or rigorous test. ${ }^{30}$ Lord Toulson himself did not deny the uncertainty. He excused it. ${ }^{31}$ Interestingly, he said (among other justifications) that law-breakers deserved less certainty than law-fearing citizens. ${ }^{32}$ The vagueness of the Patel test was evidently recognised by its supporters. They were not deluded. They were resigned.

Professor Virgo was less resigned. He regretted that the Supreme Court did not identify clear principles to guide the application of the discretionary test. In consequence, wrote Virgo, the Patel test is so vague ... it leaves open the possibility of judges resorting to arbitrary choice. ${ }^{33}$ The problem of unguided discretion was confirmed in Patel itself, Virgo continued, where the test was applied loosely:

the majority did not identify reasons why insider dealing was made a crime, or explain why this was relevant to the determination of how the defence applied. Neither were any policies identified which would have been affected had the claim been denied, nor was the question of proportionality considered explicitly. ${ }^{34}$

Before his elevation to the highest court, Professor Burrows - a proponent (indeed precursor) of the Patel test ${ }^{35}$ - expressed the hope that 'the flexible balancing approach should in time allow the formulation of ... rules that, always against a flexible background ... guide, that balancing process' ${ }^{36}$

Professors Burrows and Virgo may sit on opposite sides of the fence on Patel, but they converge in calling for a principle to guide its application. My hope is to supply this guiding principle.

It could be argued ${ }^{37}$ that such a Guiding Principle is not needed because Lord Toulson provides two guiding principles in his judgment:

Looking behind the maxims, there are two broad discernible policy reasons for the common law doctrine of illegality as a defence to a civil claim. One is that a person should not be allowed to profit from his own wrongdoing. The other, linked, consideration is that the law should be coherent and not self-defeating, condoning illegality by giving with the left hand what it takes with the right hand. ${ }^{38}$

The problem with these potential guiding principles is that Lord Toulson goes on to disapprove of the first (profiting from wrongdoing) straightaway; as did a five-member panel in Stoffel. ${ }^{39}$

As for the second principle (coherence), why, that becomes the Patel test, whose focal point is the 'integrity of the legal system'. ${ }^{40}$ The Guiding Principle cannot be the same as the test which it is supposed to guide. Nor can they be very similar. Hence my search for a Guiding Principle.

\footnotetext{
${ }^{29}$ Patel, above n 1 , at [175].

${ }^{30}$ Ibid.

${ }^{31}$ Ibid, at [113].

${ }^{32}$ Ibid.

${ }^{33}$ Virgo, above n 4 , at 761 .

${ }^{34}$ Ibid, at 759 .

${ }^{35}$ Burrows, above n 4 , at 55-56.

${ }^{36} \mathrm{Ibid}$, at 3, 17 (I took the liberty of merging, by an ellipsis, two statements with the same purport).

${ }^{37}$ N McBride 'Patel v Mirza: structured discretion or range of factors?' (2018) University of Cambridge Faculty of Law Research Paper No 66/2018 (ssrn.com/abstract=3242752) at 1.

${ }^{38}$ Patel, above n 1, at [99].

${ }^{39}$ Ibid, at [100]-[101]; Stoffel, above n 3, at [46].

${ }^{40} \mathrm{Patel}$, above n 1, at [99]-[101]; see also Stoffel, above n 3, at [22]-[23].
} 


\section{Solution}

\section{(a) Guiding Principle}

The 'Guiding Principle' is as follows:

If the claimant's harm is the ordinary result of the claimant's wrongdoing, the claim fails for illegality.

Immediately below, I try to make the Guiding Principle more precise by defining 'wrongdoing' (section (b)); showing how it would work in three real cases (section (c)); and clarifying 'ordinary result' with the help of 'Five Implications' (section (d)). In section (e), I deal with conflicts between the Implications. Lastly, to pre-empt an objection, I show how the Guiding Principle differs from Lord Hoffmann's 'wider form' in Gray $v$ Thames Trains Ltd (section (f)). ${ }^{41}$

As I make the case for the Guiding Principle, it is important to keep in mind that the Guiding Principle is just that: a guide. It is a guide for the application of the Patel test in tort. It is not intended to usurp Patel, which is accepted here as a fait accompli. Indeed, if the Guiding Principle were to produce an absurd outcome in any particular case, I would be the first to disregard it. Patel has enough flexibility to avoid an absurdity. The Guiding Principle is not a rule of law but a guide.

\section{(b) 'Wrongdoing'}

Interestingly, the cases indicate that the illegality defence does not require an illegality. Conduct which is immoral or against public policy may suffice ${ }^{42}$ (eg commercial surrogacy ${ }^{43}$ or, once upon a time, purchase of honours ${ }^{44}$ ), though a private wrong (eg breach of contract or patent infringement) would not. ${ }^{45}$ 'Wrongdoing' in the Guiding Principle is therefore defined as conduct which offends a public interest (including all crimes).

The question of who is a wrongdoer arises in the context of parasitic claims. Consider an innocent claimant who derives her claim from an offending tort victim. This may happen under the Fatal Accidents Act 1976 or the Law Reform (Miscellaneous Provisions) Act 1934. For example, a widow may sue a negligent driver for killing her husband in a road accident, where the husband was intoxicated at the time of the crash. Is she to be treated as a wrongdoer for the purposes of the Guiding Principle? Yes. The original wrongdoing contaminates the derivative claim, so to speak. As the House of Lords said in Reeves $v$ Commissioner of Police of the Metropolis, 'it is fundamental that it is the deceased's cause of action ... which is being sued on'. ${ }^{46}$ Accordingly, 'the claimant's wrongdoing' in the Guiding Principle includes wrongdoing by a tort victim from whom the action is derived.

\section{(c) Three illustrations of the guiding principle}

We may see how the Guiding Principle works by applying it to three illegality cases. The first is Vellino $v$ Chief Constable of Greater Manchester Police. ${ }^{47}$ The claimant was a petty criminal and something of an acrobat in evading arrest. He had eluded the police several times by jumping out of windows and climbing down balconies. On this tragic occasion, when he was already in police custody, he leapt from

\footnotetext{
${ }^{41}$ Gray, above n 16, at [29].

${ }^{42}$ Euro-Diam, above n 12, at 35B (Kerr LJ); Kirkham $v$ Chief Constable of the Greater Manchester Police [1990] 2 QB 283 (CA) at 291B (Lloyd LJ); Clunis v Camden and Islington Health Authority [1998] QB 978 (CA) at 987A (Beldam LJ); Nayyar v Denton Wilde Sapte [2009] EWHC 3218 (QB), [2010] PNLR 15 at [92] (Hamblen J).

${ }^{43}$ Briody $v$ St Helen's and Knowsley Health Authority (HC, 2 January 2000) at [31] (Ebsworth J).

${ }^{44}$ Parkinson $v$ College of Ambulance Ltd [1925] $2 \mathrm{~KB} 1$ (HC) at 13 (Lush J). Today the purchase of honours is an offence under $\mathrm{s} 1$ of the Honours (Prevention of Abuses) Act 1925.

${ }^{45}$ Les Laboratoires Servier, above n 21, at [28], [30] (Lord Sumption).

${ }^{46}$ [2000] 1 AC 360 (HL) at 386 (Lord Hobhouse).

${ }^{47}$ Vellino v Chief Constable of Greater Manchester Police [2001] EWCA Civ 1249, [2002] 1 WLR 218.
} 
a second-floor window and injured himself rather badly. He sued the police in negligence for failing to prevent his predictable escape. Assuming negligence for the moment, should the claimant recover despite the illegality of his conduct?

Applying the Guiding Principle, we first ask if there was 'wrongdoing' by the claimant. Escaping arrest is a common law offence so the answer is yes. Secondly, we ask whether the claimant's harm (physical injury) was the 'ordinary result' of the claimant's wrongdoing (the escape). The answer is yes. Jumping from a second storey is very dangerous. Hence the Guiding Principle suggests the claim should fail. And so it did. ${ }^{48}$

The second illustration of the Guiding Principle is a criminal earnings case, Burns $v$ Edman. The claimant's husband was killed in a road accident through the negligence of the defendant. The claimant widow sued for loss of support under the Fatal Accidents Act 1846. Since the deceased had lived a life of crime, the lost support in question was really proceeds of crime. The claim failed for illegality. ${ }^{49}$

Does the Guiding Principle lead to the same outcome? We begin with wrongdoing. Is the claimant widow a wrongdoer? The claimant derives her claim from a criminal. Moreover, she herself seeks recovery of wrongful earnings. As explained in the last section, which deals with derivative claims, the wrongdoing requirement is satisfied. Next we ask if the claimant's harm - the loss of support - is an ordinary result. No thief expects a court to hand over to him the thing he has stolen. The loss of support is therefore to be expected. The Guiding Principle indicates the claim should fail. If we generalise this argument, we see that the Guiding Principle does not allow recovery of criminal earnings.

The third case chosen to illustrate the Guiding Principle is the recent Supreme Court decision in Stoffel. The claimant bought a property with the help of a mortgage. The solicitors failed to register the transfer of title so the claimant never became legal owner of the land. She sued her solicitors in negligence. The solicitors invoked the illegality defence inasmuch as the mortgage had been obtained by fraud.

We apply the Guiding Principle. There is no doubt that fraud is wrongdoing. Is the solicitors' incompetence the ordinary result of dishonest borrowing? No. The two things are unconnected. Solicitors are always expected to be competent. The careless failure to register was not even (unintentionally) useful in combating fraud because, by that stage, the loan had been advanced. The solicitors' negligence was not an ordinary result. The Guiding Principle thus says the claimant should recover. The Court came to the same conclusion. ${ }^{50}$

\section{(d) 'Ordinary result': five implications}

By 'ordinary', I mean no more than the dictionary definition of the word: 'not different or special or unexpected in any way; usual. ${ }^{51}$ 'Ordinary result' in the Guiding Principle has five important implications. These Implications tell us, or at least help us determine, whether the claimant's harm is an ordinary result. For the avoidance of doubt, we now assume that the wrongdoing requirement (Section (b) above) is satisfied.

To be clear, I do not claim that the Guiding Principle or its Implications were used by the judges in the cases we are about to discuss. The Guiding Principle originates here, so no case uses it. I re-reason the cases in terms of the Implications.

\section{(i) Independent harm is not ordinary (claim succeeds)}

Harm whose cause is entirely independent of the claimant's wrongdoing is not an ordinary result of the wrongdoing. For instance, while A is duelling with B, A is unexpectedly shot by C. While a duel

\footnotetext{
${ }^{48}$ Ibid, at [70]-[71] (Sir Murray Stuart-Smith), [34]-[37] (Schiemann LJ).

${ }^{49}$ Burns $v$ Edman [1970] 2 QB 541 (HC) at [544]-[546] (Crichton J).

${ }^{50}$ Stoffel, above n 3, at [27]-[35], [40] (Lord Lloyd-Jones). In another leading case involving fraud, Stone \& Rolls Ltd $v$ Moore Stephens [2009] UKHL 39, [2009] 1 AC 1391, the defence was made out. The successful defrauding of auditors was the ordinary result of a company seeking to do just that.

${ }^{51}$ Cambridge Dictionary: https://dictionary.cambridge.org/dictionary/english/ordinary (accessed 5 May 2021).
} 
ordinarily results in harm, unrelated harm by a stranger is not the ordinary result of a duel. Ergo, 'ordinary result' excludes harm caused independently of the claimant's wrongdoing.

A case in point is McCracken $v$ Smith. A collision between a motorcycle and bus had two independent causes - the rider's dangerous driving and the bus driver's unrelated failure to watch the road. ${ }^{52}$ The claimant was the pillion passenger. His illegality was aiding and abetting the rider's dangerous driving. The claimant sued both the rider and the bus driver for his serious injuries. The two claims nicely illustrated the difference between independent harm and dependent harm, which is the point of this Implication 1 . The illegality defence barred the claim against the rider. ${ }^{53}$ An accident is the 'ordinary result' of dangerous driving, which was encouraged by the claimant. But the illegality defence did not bar the claim against the bus driver. The bus driver's negligence was an independent cause of the claimant's harm. $^{54}$

Another example is National Coal Board v England. The claimant coal-miner breached safety regulations, but was injured as a result of a co-worker's separate breach of the regulations. The claim succeeded. ${ }^{55}$ Other examples include: Mode $v$ Southern Rock Insurance Co Ltd (car accident) $;{ }^{56}$ Edwards v Jerman (car accident); ${ }^{57}$ Sweetman $v$ Nathan (fraud); ${ }^{58}$ and the aforementioned Stoffel (fraud).

\section{(ii) Costs of conviction are ordinary (claim fails)}

Being convicted of a crime is an ordinary result of committing the crime. This is because the conviction (and sentence) are the legally-stipulated result of the conduct - ie what the public is told to expect. Hence, 'ordinary result' includes criminal penalties (eg imprisonment and fines) and the consequential harm flowing from a criminal conviction (eg loss of reputation and earnings). This Implication 2 corresponds to Lord Hoffmann's 'narrow rule' in Gray. ${ }^{59}$

A case in point is Clunis $v$ Camden and Islington Health Authority. The claimant had been a mental patient. Negligently discharged from hospital, he stabbed a man to death and was convicted of manslaughter. The claimant sued the health authority in negligence for his prolonged detention consequent on the conviction. The Court of Appeal held the illegality defence defeated the claim. ${ }^{60}$ The detention was the cost of the conviction and thus ordinary.

Other examples of claimants failing to recover losses associated with their own conviction are: Gray (manslaughter); ${ }^{61}$ Henderson (manslaughter); ${ }^{62}$ Worrall $v$ British Railways Board (sexual assault); ${ }^{63}$ Askey $v$ Golden Wine Co Ltd (violation of food safety regulations); ${ }^{64} R$ Leslie Ltd $v$ Reliable Advertising and Addressing Agency Ltd (advertising loans to a minor); ${ }^{65}$ Day $v$ Womble Bond Dickinson (UK) LLP (illegal construction), ${ }^{66}$ and, in obiter, Colburn v Patmore (criminal libel). ${ }^{67}$

(iii) Innocent wrongdoers do not foresee the ordinary consequences of wrongdoing (claim succeeds) Sometimes the claimant does not realise that what she is doing is wrong. A claimant may be subjectively innocent in this sense if, for instance, she commits a strict liability offence, is deceived, or has no

\footnotetext{
${ }^{52}$ [2013] EWHC 3620 (QB) at [59] (Richards LJ).

${ }^{53}$ Ibid, at [1], [11], [24], [43], [48] (Richards LJ).

${ }^{54}$ Ibid, at [50]-[53] (Richards LJ), [87] (Christopher Clarke LJ).

${ }^{55}$ [1954] AC 403 (HL) at 428-429 (Lord Asquith).

${ }^{56}$ Northampton County Court, 19 September 2014 (unreported) at [6]-[7] (Judge Calnan).

${ }^{57}$ [2004] CLY 2743 (Liverpool County Court).

${ }^{58}$ [2003] EWCA Civ 1115, [2004] PNLR 7 at [63] (Schiemann LJ).

${ }^{59}$ Gray, above n 16, at [29].

${ }^{60}$ Clunis, above n 42, at 987A-B, 989D-990E (Beldam LJ).

${ }^{61}$ Gray, above n 16, at [48], [50] (Lord Hoffmann).

${ }^{62}$ Henderson, above n 3, at [125]-[150] (Lord Hamblen).

${ }^{63}$ [1999] CLY 1413 (CA).

${ }^{64}[1948] 2$ All ER 35 (HC) at 38 (Denning J).

${ }^{65}$ [1915] $1 \mathrm{~KB} 652(\mathrm{HC})$ at 658, 661 (Rowlatt J).

${ }^{66}$ [2020] EWCA Civ 447, [2020] PNLR 19 at [63], [70]-[74] (Lord Coulson).

${ }^{67}$ (1834) 1 CrM\&R 73 (Exchequer) at 83-84 (Lord Lyndhurst CB).
} 
understanding of right and wrong. Since it is impossible to foresee the consequences of something unknown, 'ordinary result' excludes the consequences of wrongdoing by subjectively-innocent claimants. For the avoidance of doubt, the point here is not that the claimant does not foresee the consequences as such. The point is that she does not foresee the consequences as being the ordinary result of wrongdoing - because she is oblivious to the wrongdoing.

The cases bear witness to this Implication. In the remarkable case of Burrows $v$ Rhodes, arising from the Jameson Raid of 1895, the claimant was tricked into invading a neighbouring republic as a soldier in a private army, all the while believing he was serving in Her Majesty's forces. He sustained lasting injuries. The claimant's participation in the invasion was a crime under the Foreign Enlistment Act 1870. He was never prosecuted; but his tortious claim for fraud against the organisers of the invasion was met with the illegality defence. He recovered notwithstanding. ${ }^{68}$ In our terms, he was personally innocent and thus could not foresee the ordinary consequences of wrongdoing.

Further authority for this Implication 3 is found in Griffin $v$ UHY Hacker Young \& Partners (unknowing contravention of the Insolvency Act 1986) ${ }^{69}$ and Shelley $v$ Paddock (unknowing contravention of the Exchange Control Act 1947). ${ }^{70}$

\section{(iv) Anomalous response by the defendant is not ordinary (claim succeeds)}

This Implication is so obvious as to be a tautology. I state it to emphasise that 'ordinary result' excludes grossly-disproportionate harm inflicted on the claimant by the defendant (eg a stabbing in retaliation for rudeness).

A case in point is Flint $v$ Tittensor. The claimant verbally attacked the defendant, who was sitting in a car, and dented the car with his fist. The defendant drove the car towards the claimant, causing him to fall onto the bonnet; then carried him a considerable distance on the bonnet; and finally, steering sharply, threw the claimant off the bonnet, causing him injury. Edis J contrasted the claimant's 'relatively minor criminality' with the defendant's 'serious criminal offences'. The illegality defence was rejected. ${ }^{71}$ In our terms, the defendant's grossly-disproportionate response was extraordinary.

A counter-example is Cross v Kirkby. Here the defendant's response to the claimant's violence was legitimate self-defence. As the Guiding Principle would envisage, the illegality defence was held to apply. $^{72}$

Other examples include: McHugh v Okai-Koi (altercation very similar to Tittensor); ${ }^{73}$ Levitt $v$ Euro Building and Maintenance Contractors Ltd (altercation) $;{ }^{74}$ Lane $v$ Holloway (altercation), ${ }^{75}$ Revill $v$ Newberry (homeowner shoots burglar). ${ }^{76}$

This proportionality exercise makes Implication 4 the only discretionary Implication. And it exposes the Guiding Principle to the objection that it is no less vague than the proportionality limb in Patel (that is 'whether denial of the claim would be a proportionate response to the illegality...').

My answer is that the proportionality in Implication 4 is less vague than in Patel. This is because the former compares two things that are of the same kind: the claimant's actions and the defendant's actions: apples and apples. The same is true of the contextual circumstances that fall to be compared, like the parties' respective ages, expertise or motives.

\footnotetext{
${ }^{68}[1899] 1$ QB 816 (HC) at 827 (Grantham J), 833-834 (Kennedy J).

${ }^{69}$ [2010] EWHC $146(\mathrm{Ch})$, [2010] PNLR 20 at [58]-[62] (Vos J) (preliminary).

${ }^{70}[1980] 1$ QB $348(\mathrm{CA})$ at $356 \mathrm{D}-357 \mathrm{C}$ (Lord Denning MR).

${ }^{71}$ [2015] EWHC 466 (QB), [2015] 1 WLR 4370 at [26]-[27], [42]-[43], [54]-[56].

${ }^{72}$ Cross, above n 15, at [78] (Beldam LJ), [91], [125]-[126] (Judge LJ). The Court of Appeal suggests, in the cited paragraphs, that the defence of illegality would apply even if the defendant's response were disproportionate (though up to a point). I do not address this because, as already stated, I do not pretend that the Guiding Principle was used in the cases. Judges used a variety of tests. I re-reason the cases to show that the Guiding Principle explains the outcomes.

${ }^{73} \mathrm{McH} u g h$, above n 25, at [1], [11], [19]-[24] (Judge Pittaway).

${ }^{74}[2019]$ EWHC 2926 (QB) at [96]-[99] (Judge Freedman).

${ }^{75}[1968] 1$ QB 379 (CA) at 385F-387B (Lord Denning MR).

${ }^{76}[1996]$ QB 567 (CA) at 571F, 577D (Neill LJ); cf Murphy v Culhane [1977] 1 QB 94 (CA) at 98E-G (Lord Denning MR) (preliminary).
} 
By contrast, the proportionality limb in Patel compares apples and oranges: the claimant's actions and the denial of the claim. That is like asking, What is higher: 30 degrees or 30 meters? ${ }^{77}$ Besides, Patel has three separate limbs, all of which are discretionary and incommensurable inter se. So I grant the Guiding Principle has a degree of discretion, but it is much narrower than the corresponding limb in Patel, let alone the whole of Patel.

\section{(v) Expenses of wrongdoing are ordinary (claim fails)}

Loss of expenses that the claimant would have incurred anyway, for the purpose of the wrongdoing, is an ordinary result of the wrongdoing. Thus, 'ordinary result' includes, without limitation: a bribe; the price of a gun; a fee paid to a forger; or monies owed to solicitors who facilitate a fraudulent transaction. Since this outlay was intended as part of the wrongdoing, it is expected and ordinary.

A case in point is Nayyar $v$ Denton Wilde Sapte. The claimants pursued a business opportunity in India. On the advice of their lawyers, the claimants made payments that were obviously bribes (though disguised as deposits). The bribes failed to secure the desired contract. The disappointed claimants sued their lawyers in negligence to recover the amount of the bribes. The defence of illegality barred the claim. ${ }^{78}$ In our terms, the bribe was always going to be an expense of the illegality and thus ordinary.

Other examples include Marsh $v$ Chief Constable of Lancashire (joining fee for criminal racket and stolen goods); $;^{79}$ Parkinson $v$ College of Ambulance Ltd (bribe); ${ }^{80}$ Taylor $v$ Chester (goods connected with prostitution); ${ }^{81}$ Briody $v$ St Helen's and Knowsley Health Authority (commercial surrogacy). ${ }^{82}$

One may suppose that the payment recovered in Patel was likewise an expense of the wrongdoing since it was necessary for insider trading. If that were so, the Guiding Principle would incorrectly predict that the defence should bar the claim. But it is not so. First of all, Patel was not a tort case so the Guiding Principle does not purport to explain it.

More importantly, the Guiding Principle would explain Patel even if it were a tort case. This is because the payment in Patel was a principal, not an expense. A principal is a sum to be invested. An expense is a sum forfeited absolutely. Since Mr Patel's payment was a principal, this Implication 5 is not engaged.

More broadly, the 'ordinary result' of insider trading is that the money would be invested (ie remain an asset), not incurred in the transaction (ie be paid as a liability). ${ }^{83}$ What transpired in Patel was the opposite of the ordinary result: instead of having his asset invested, the claimant was deprived of it. The Guiding Principle would thus explain Patel, even if Patel needed explaining.

\section{(e) Hierarchy of implications}

What do we do when different Implications, pointing in opposite directions, apply to the same set of facts? Examples include a convicted but subjectively-innocent claimant (overlap of 2 and 3) or an expense incurred for an unknowingly wrongful purpose (overlap of 3 and 5). Given that one Implication points to recovery and the other to dismissal, we need to decide which Implication is stronger. We need a hierarchy of Implications.

As already stated, the Guiding Principle is merely a guide. The following hierarchy, which elaborates on this guide, should be read in the same light. It is not intended to be prescriptive, let alone in exceptional cases. The purpose of this hierarchy is further to clarify the operation of the Guiding Principle in the usual run of cases.

\footnotetext{
${ }^{77}$ See R Stevens Torts and Rights (Oxford University Press 2007) p 310.

${ }^{78}$ Nayyar, above n 42, at [120]-[121] (Hamblen J).

${ }^{79}$ [2003] EWCA Civ 284, (2003) 100(18) LSG 36 at [30]-[31] (Potter LJ).

${ }^{80}$ Parkinson, above n 44, at [13] (Lush J); cf Lord Neuberger, who considered this case wrongly decided: Patel, above n 1, at [150].

${ }^{81}$ (1869) LR 4 QB 309 (Exchequer Chamber) at 312, 315 (Mellor J).

${ }^{82}$ Briody, above n 43, at [23], [31] (Ebsworth J).

${ }^{83}$ This is to be distinguished from other two-party quid pro quo transactions (like the assassination contract), where the payment is expected from the outset to be incurred as a liability, not retained as an asset.
} 
The hierarchy suggested here is embedded in the numbering of Implications. The Implication number is its rank, such that Implication 1 (independent harm) is the strongest and 5 (expense) the weakest. I give reasons for this ranking presently.

Implication 1 (independent harm) supersedes all other Implications because the harm, by definition, has nothing to do with the claimant's wrongdoing. It is a coincidence. Even if the claimant is convicted of the illegality, the conviction is not undone by awarding compensation for an unrelated tort. Suppose a road accident involving two drivers, A and B, is entirely due to the fault of B; but A happens to be intoxicated. It is submitted that A would recover damages from B even if A were convicted and fined for drink-driving. In such case, recovering damages would undo the fine as much as winning the lottery would. Implication 1 accordingly ousts all other Implications. (Technically, it does not oust Implication 3, which has the same outcome.)

Implication 2 (conviction) displaces Implications 3 (innocence) and 4 (anomalous response) and has the same result as 5 (expense). In the first place, relieving the claimant from the consequences of a conviction (which is not independent of the harm), by allowing him to recover compensation therefor, would undo the conviction and sow contradiction between courts. The result would be 'an intolerable fissure in the law's conceptually seamless web'. ${ }^{84}$ This 'consistency principle' greatly influenced the Supreme Court in Henderson. ${ }^{85}$ It was the basis for Lord Hamblen's conclusion that the claimant's innocence did not matter. What mattered was the conviction. ${ }^{86}$

In the second place, if we must choose between the decision of the criminal court and of the civil court, we should prefer the former. The criminal court has a higher standard of proof, more procedural safeguards for the accused (the tort claimant) and often takes into account the very considerations in Implications 3 and 4 (subjective innocence and proportionality). There is therefore no need or justification for the civil court to unravel or countermand the criminal conviction.

Implication 3 (innocence) surpasses Implication 5 (expense) and has the same result as 4 (anomalous response). The conflict between Implications 3 and 5 arises where the claimant incurs an expense for a purpose which, unbeknownst to the claimant, is wrongful. In such a case, it would seem the claim should not fail for illegality. As we recall, the reason that subjectively-innocent claimants do not foresee the harm ordinarily resulting from their wrongdoing is that they are unaware of the wrongdoing. That the harm takes the form of an expense is nothing to the point. The claimant does not foresee any harm from wrongdoing.

Implications 4 and 5 have the same result so it is never necessary to choose between them. The two lowest rungs of the hierarchy are thus randomly assigned.

\section{(f) Contrast with 'wider form'}

In Gray, Lord Hoffmann described the illegality doctrine as a 'rule of public policy' which comes in two forms. The 'narrower form' parallels Implication 2 (conviction) - as stated thereunder. The 'wider form' is that 'you cannot recover compensation for loss which you have suffered in consequence of your own criminal act'. ${ }^{87}$ This may appear to be the same as the Guiding Principle, but it is not.

To begin with, the Guiding Principle has a subjective element (in Implication 3), whereas Lord Hoffmann's wider form is wholly objective. More significantly, the wider form is concerned only with causation. The Guiding Principle takes into account causation and remoteness (in the form of ordinariness). The wider form does not take into account, at least explicitly, the issue of remoteness. Finally, the Guiding Principle is more detailed than the wider form. Witness the discussion above regarding Implications. All this nuance is absent from Lord Hoffmann's dictum.

\footnotetext{
${ }^{84}$ EJ Weinrib 'Illegality as a tort defence' (1976) 26 University of Toronto Law Journal 28 at 42; quoted approvingly in Les Laboratoires Servier, above n 21, at [24] (Lord Sumption).

${ }^{85}$ Recently confirmed in Henderson, above n 3, at [97]-[112], [125], [128] (Lord Hamblen); see also Hall v Hebert [1993] 2 SCR 159 (Canada Supreme Court) at 182 (McLachlin J).

${ }^{86}$ Henderson, above n 3, at [83], [86], discounting dicta in Gray, above n 16, [15] (Lord Phillips), [83] (Lord Rodger), [103] (Lord Brown); cf J Goudkamp 'The defence of illegality: Gray v Thames Trains Ltd' (2009) 17 Torts Law Journal 205 at $209-211$.

${ }^{87}$ Gray, above n 16, at [29].
} 
Due to these three differences, the Guiding Principle and the wider form beget different outcomes. We can see this in Robinson $v$ Ness \& Co. The claimant was convicted of contraventions of planning law. He sued his solicitors in negligence for failing to advise him to obtain planning consent. Broadly, two heads of loss were claimed: criminal fines; and costs of various civil proceedings arising from the illegality. The claim failed in respect of the criminal costs and succeeded in respect of the civil costs. The wider form cannot explain this outcome because both types of damage were caused by the claimant's illegality. The Guiding Principle does explain the outcome. Fines could not be recovered by virtue of Implication 2 (conviction). Civil costs could be recovered: the judge found they did not flow from the conviction (Implication 2 does not apply); ${ }^{88}$ and the claimant was sufficiently subjectively innocent (Implication 3). ${ }^{89}$

Another case that confirms the difference between the Guiding Principle and the wider ground is Morgan $v$ Bryson Recycling Ltd. The claimant's parked car was damaged through the defendant's negligent driving. The claimant sued for property damage and for the hire of a replacement car. The illegality was that the claimant's car was neither roadworthy nor insured. The claim for property damage succeeded and the claim for hire failed. ${ }^{90}$ Again, the wider form cannot explain this as both heads of loss were a consequence of the car being on the road illegally. According to the Guiding Principle, however, property damage should be recoverable. It was not in the ordinary course of events that lack of a test certificate or insurance would result in another driver crashing into one's parked car. The hire charges were not recoverable because inability to drive is precisely the ordinary result of having no test certificate or insurance. The same result as to hire charges, on materially the same facts, was reached in Agheampong $v$ Allied Manufacturing (London) Ltd. $^{91}$

In conclusion, the Guiding Principle shares some attributes with Lord Hoffmann's wider form, but the former is different and more detailed, leading to opposite outcomes. To be sure, my aim is not to discredit Lord Hoffmann's valuable contribution to the illegality debate. On the contrary, the Guiding Principle may be seen as a development of Lord Hoffmann's influential insight.

\section{Normative validity}

I preface the argument for normative validity by identifying a normative framework. Tort law is normally seen through one of two normative lenses: corrective justice; or instrumentalism (or a 'pluralist' combination of both). ${ }^{92}$ Corrective justice views tort as an attempt to undo an injustice between parties, disregarding broader questions of public policy. ${ }^{93}$ Instrumentalism is the opposite: it sees tort law as a means to some social or economic end that transcends the parties.

The illegality defence, as conceived by the courts, appears to rest more naturally on instrumentalism than corrective justice. In the seminal case of Holman $v$ Johnson, Lord Mansfield CJ was forthright on this point:

It is not for [the defendant's] sake, however, that the [illegality defence] is ever allowed; but it is founded in general principles of policy, which the defendant has the advantage of, contrary to the real justice, as between him and the plaintiff, by accident, if I may so say. ${ }^{94}$

\footnotetext{
${ }^{88}$ [2017] EWHC 2305 (Ch) at [174]-[177], [180] (Judge Murray).

${ }^{89} \mathrm{Ibid}$, at [112], [121], [178] (Judge Murray).

${ }^{90}$ [2018] NIQB 12 at [2]-[4], [9]-[10] (Burgess J). There was also a storage claim, treated as an extension of the property damage claim, which was granted in principle, but failed for lack of evidence: at [11].

${ }^{91}$ [2009] Lloyd's Rep IR 379 (CC) at [136]-[137] (Judge Dean); cf Jack v Borys, Newcastle CC, 20 December 2019 (unreported) at [11] (Judge Freedman).

${ }^{92}$ See eg EJ Weinrib Corrective Justice (Oxford University Press, 2012) p 9; GT Schwartz 'Mixed theories of tort law' (1997) 75 Texas Law Review 1801 at 1801, 1834.

${ }^{93}$ Weinrib, ibid, at pp 16, 19, 24.

${ }^{94}$ Holman v Johnson (1775) 1 Cowp 341, 98 ER 1120 (Court of KB) at 1121.
} 
In Patel, Lord Toulson referred to this comment with apparent approval and held that the doctrine was rooted in public policy. ${ }^{95}$ Since the focus is public policy and not justice between parties, I proceed on the basis that the relevant normative framework is instrumentalism.

Parenthetically, it may well be that the illegality defence is, after all, reconcilable with corrective justice. The theory's major exponent, Professor Weinrib, warns against the 'misconception ... that corrective justice is a substantive rather than a structural principle'. ${ }^{96}$ The 'injustice' implied in corrective justice is not defined by the theory, but by the legal system: 'the concepts and principles of tort liability set out the conditions under which the defendant's conduct counts as [injustice]'. ${ }^{97}$ If so, the wrongdoing may mean there is no injustice for the purposes of corrective justice. But even if corrective justice can accommodate the illegality doctrine, it cannot justify it. For illegality is a matter of legal substance - as to which the theory is indifferent. The opposite of the illegality defence would be just as compatible with corrective justice.

To conclude the preface, any justification of the Guiding Principle must be instrumental. It is to be found in public policy.

My methodology for this paper was to examine the case law in search of a method in the madness. I believe I have found it in the Guiding Principle. But consistency does not equal quality. A principle may be consistent and bad. This section asks if the Guiding Principle is good in a normative sense. What we are looking for is an objective (public policy) justification, admittedly in retrospect. Is there a reason why tort claims, affected by illegality, should turn on whether the claimant's harm is the ordinary result of the claimant's wrongdoing; or is 'ordinary result' a random fact that happens to correlate with case outcomes?

I argue that it is not a random fact. There is a justification for the Guiding Principle, regardless of the correlation with the cases. Put differently, we would want the Guiding Principle to guide our law even if cases were not already aligned with it.

Before we come to this justification, let us dwell momentarily on the fact that the Guiding Principle is not a known rule. Judges do not consciously apply it. Rather, it is a hidden pattern or tendency, immanent in the cases. This very hiddenness suggests that there is a good reason for the Guiding Principle. A hidden principle is less likely to be bad than an explicit principle. A bad but explicit principle may be applied because judges are bound by it; or, even if not bound, they may be influenced by it. By contrast, an unknown principle cannot survive through authority or influence, having neither. If judges repeatedly and voluntarily come to the same view, it is probable that this view has merit. If judges are under no pressure to apply the Guiding Principle, but do so in effect, it is probable that the Guiding Principle represents some relevant concept. Therefore, it is improbable that the Guiding Principle is a coincidental correlation.

Now we come to the objective justification for the Guiding Principle. In short, the justification is that the claimant is - normally - an illegal-risk-taker (where 'illegal' modifies 'risk', not 'taker'). We can think of wrongdoing as a bet against the legal system. Thus, if the claimant pays a bribe, she assumes the risk of detection and punishment, in exchange for the promise of advantage. She bets on not getting caught.

Generally, the law does not assist risk-takers - because the essence of risk-taking is that the risktaker bears the costs of the risk materialising, just as he benefits in the opposite case. That is the meaning of taking the risk.

This refusal to relieve risk-takers of the risk they have taken manifests itself across private law. A few examples will suffice. In unjust enrichment, risk-taking may sink the claim: 'The real point', said

\footnotetext{
${ }^{95}$ Patel, above n 1, at [91], [99], [101], [120].

${ }^{96}$ Weinrib, above n 92, p 10.

${ }^{97}$ Ibid, pp 20-21.
} 
Lord Hoffmann, 'is whether the person who made the [mistaken] payment took the risk that he might be wrong. If he did, then he cannot recover the money'. ${ }^{98}$ In contract, risk-taking bars recovery for common mistake ${ }^{99}$ and may prevent the implication of a term: 'under a contract like the present the agent takes a risk'; 'It is the risk that he runs and that he must be taken as being willing to run'. ${ }^{100}$ In tort, the complete defence of volenti non fit injuria leaves risk-takers uncompensated. The defence is narrow, ${ }^{101}$ but the underlying principle is clear. It finds expression more often in the partial defence of contributory negligence. Damages are reduced in proportion to the claimant's unreasonable risking of his own safety. ${ }^{102}$ The same concept re-appears in statutory form to limit occupiers' liability: 'The common duty of care does not impose on an occupier any obligation to a visitor in respect of risks willingly accepted...'103

If the law is deaf, or at least hard-of-hearing, to the plea of a risk-taker, should it be all ears to the illegal-risk-taker? Shall we give villains what we deny saints? As long as we hold risk-takers to their bargains (and we should), we cannot waive this principle for the least worthy risk-takers - wrongdoers. This is the justification for the Guiding Principle. Risk-takers in general do not recover. A fortiori, illegal-risk-takers should not recover.

In instrumentalist terms, the law perforce has an interest in sanctioning illegal-risk-taking - as such bets are by definition against the law. The Guiding Principle is thus a principal guardian of the law. Indeed, it promotes the important social and economic goal known as the rule of the law.

I now deal with three potential counter-arguments to the cogency of illegal-risk-taking as a normative justification. It may be objected that the gambling analogy is true of all claims stained by illegality. If so, should not all such claims fail? What is so special about claims caught by the Guiding Principle? However, the premise of this objection is wrong. The gambling analogy is not true of all illegality cases. If the harm is extraordinary (hence outside the Guiding Principle), the claimant cannot be said to have taken the risk. The law does not hold people responsible for any conceivable risk they take, however slight. ${ }^{104}$ Not all offending claimants are unlucky risk-takers. The Guiding Principle captures those claimants who are clearly risk-takers by focusing on the ordinary result of the illegality. This is why the justification supports the Guiding Principle specifically, if not uniquely.

There is another objection to the risk-taking justification. What about claimants who are not aware of their wrongdoing? How can they be said to have taken the risk? It is true that, by and large, the Guiding Principle does not deny recovery to subjectively-innocent claimants (as per Implication 3). But there is one situation where it does: if they are convicted of an offence. It will be recalled that Implication 2 (conviction) trumps Implication 3 (innocence). This is a wrinkle in the normative case for the Guiding Principle because the claimant cannot be said to have taken the risk.

My answer to this objection is that the legal system has decided that in certain situations a guilty mind - mens rea - is not an element of a crime. If so, neither is it an element of taking the risk of that

\footnotetext{
${ }^{98}$ Deutsche Morgan Grenfell Group plc v Inland Revenue Commissioners [2006] UKHL 49, [2007] 1 AC 558 at [26]. Some risk-takers have nevertheless recovered in unjust enrichment: F Wilmot-Smith 'Replacing risk-taking reasoning' (2011) 127 Law Quarterly Review 610 at 614-615. Still, while not always fatal, risk-taking militates against recovery. It is a reason why a claimant should not recover.

${ }^{99}$ Associated Japanese Bank (International) Ltd v Credit du Nord SA [1989] 1 WLR 255 (HC) at 268B (Steyn J); Great Peace Shipping Ltd v Tsavliris Salvage (International) Ltd [2002] EWCA Civ 1407, [2003] QB 679 at [84] (Lord Phillips MR).

${ }^{100}$ Luxor (Eastbourne) Ltd v Cooper [1941] AC 108 (HL) at 150 (Lord Wright), 153 (Lord Romer); see also 120 (Viscount Simon LC), 124 (Lord Russell), 141 (Lord Wright).

${ }^{101}$ Nettleship $v$ Weston [1971] 2 QB 691 (CA) at 701 (Lord Denning MR); Morris v Murray [1991] 2 QB 6 (CA) at 18 (Stocker LJ).

${ }^{102}$ Froom v Butcher [1976] QB 286 (CA) at 291G-292B (Lord Denning MR); Law Reform (Contributory Negligence) Act 1945 , s 1 .

${ }^{103}$ Occupiers Liability Act 1957, s 2(5); Occupiers Liability Act 1984, s 1(6).

${ }^{104}$ Bolton $v$ Stone [1951] AC 850 (HL) at 860-862 (Lord Normand).
} 
crime. The criminal law places the risk of ignorance on the offender. If the offender then becomes a civil claimant, he is deemed to have taken the risk without a guilty mind. For example, a driver who honestly mistakes the speed limit is nevertheless guilty of speeding. It is the driver's responsibility to know the speed limit. It is his problem: his risk. The Guiding Principle reflects this position. The normative justification still holds: claimants caught by the Guiding Principle should not recover because they are illegal-risk-takers. It just so happens that taking the risk of certain illegalities does not depend on a guilty mind.

Finally, I must address a more fundamental objection to the risk-taking analysis. Dr Frederick Wilmot-Smith argues that the risk-taking analysis is circular. He made the argument in 2011, in the context of unjust enrichment. Translated to the illegality context, the argument (I take the liberty to assume) would run as follows. The claimant can only be said to have taken a risk if we presuppose that he cannot recover by reason of the illegality. (For if he can recover, the risk is shifted to the defendant.) So the claimant is a risk-taker because we deny him recovery, and we deny him recovery because he is a risk-taker. The conclusion is in the premise. The argument is circular. ${ }^{105}$

With respect, this criticism of the risk-taking analysis seems to me misguided. Suppose a lifeguard decides to save a drowning person. This seems sensible enough. But if we accepted Wilmot-Smith's circularity argument, we would have to reject the basis for the lifeguard's decision as circular. For drowning depends on not being rescued. The person will drown only if we presuppose that the lifeguard does not save him!

But the lifeguard's policy is clearly valid and useful. The lifeguard is entitled to adopt the policy: 'Rescue any person who is at risk of drowning if not rescued'. In the illegality context, similarly, we are entitled to adopt the policy: 'Do not rescue a claimant who will suffer the consequences of an illegal risk he has taken - if not rescued' (by the court granting his claim). In truth, these propositions are only as circular as any deductive reasoning is circular. Mathematical proof is perfectly circular since each line must logically follow from the preceding line. And yet, mathematics is valid and very useful. Therefore, risk-taking analysis is not to be rejected for circularity.

\section{Conclusion}

Patel v Mirza is the status quo on illegality. I have no wish to disturb it. My wish is to guide the discretion in the Patel test, answering the call of Burrows and Virgo. My aim is not to displace Patel, but to bring clarity and consistency to its (discretionary) application across a large body of disparate case law. To this end, this paper identifies a principled basis for the application of the Patel test in the domain of tort. This basis is the Guiding Principle and five sub-principles, called Implications.

It is contended, in Part 1, that principled guidance is needed because Patel is unpredictable. Part 2 sets out the Guiding Principle along with its Implications. In addition, Part 2 shows that the Guiding Principle is already reflected in the case law to a high degree. Thus are reconciled the apparent contradictions on the surface of the case law. Part 3 makes the normative case for the Guiding Principle, to wit, that illegal-risk-takers are undeserving claimants, who should not be treated more favourably than legal-risk-takers.

It is fitting to end with the scenario that started this inquiry. We asked whether a claimant fooled by a false hitman could recover the assassination fee in an action for fraud. The Guiding Principle answers this question. The answer is no. An assassination fee falls within Implication 5 (expense). The claim should fail.

Should an actual claimant be bold enough to reclaim an assassination fee, let us hope the judge would reply, with greater boldness, ex turpi causa non oritur actio.

\footnotetext{
${ }^{105}$ Wilmot-Smith, above n 98 , at 613.
}

Cite this article: Shmilovits L (2021). When is illegality a defence to a tort? Legal Studies 41, 603-616. https://doi.org/ $10.1017 /$ lst.2021.23 